\section{Аитература}

1. Комлев Н.Г. Словарь иностранных слов. - М.: ЭКСMO. - 2006. - 672 c.

2. Концепция развития системы здравоохранения в Российской Федерации до 2020 г. // Электронный ресурс. Режим доступа: http://topmedicina.ru/health/koncepciya.

3. Парахонский А.П. Медицинское образование сегодня и пути его совершенствования // Успехи современного естествознания. - 2008. - № 9. - С. 60-61.

4. Скворцова В.И. Модернизация системы медицинского образования и кадрового обеспечения / В.И. Скворцова // Электронный ресурс. - Режим доступа: http://www. zdrav.ru/articles/interview/detail.php?ID $=7252$

\section{Сведения об авторах}

Артюхов Иван Павлович - g.м.н., проф., ректор Красноярского госуgарственного меgицинского университета им. проф. В.Ф. Войно-Ясенецкого; е-таil: rector@krasgmu.ru.

Зуков Руслан Александрович - к.м.н., gоцент, уекан лечебного факультета Красноярского государственного меgицинского университета им. проф. В.Ф. Войно-Ясенецкого; е-mail: zukov_rus@mail.ru.

Виник Юрий Семенович - g.м.н., проф., зав. каф. общей хирургии Краснояр- ского государственного меgицинского университета им. проф. В.Ф. Войно-Ясенецкого; e-mail:yuvinnik@yandex.ru.

Зgзитовецкий дмитрий Эgуарgович - к.м.н., gоцент, зав. кафеgрой и клиникой хирургических болезней им. проф. Ю.М. Аубенского Красноярского госуgарственного меgищинского университета им. проф. В.Ф. Войно-Ясенецкого; e-mail: zdz64@mail.ru.

Черяанцев Амитрий Влаgимирович - g.м.н., проф., зав. кафеgрой и кииникой хирургических болезней им. проф. А.М. Аыхно с курсом эндоскопии и эняохирургии ПО Красноярского госуgарственного меgицинского университета им. проф. В.Ф. Войно-Ясенецкого; е-таil: gs7@mail.ru.

Данилина Елена Петровна - к.м.н., gоцент кафеgры и кииники хирургических болезней им. проф. Ю.М. Аубенского Красноярского государственного меgицинского университета им. проф. В.Ф. Войно-Ясенецкого ; e-mail: danjuly@rambler.ru.

Белобородов Алексей Александрович - к.м.н., gоцент кафеgры и клиники хирургических болезней им. проф. Ю.М. Аубенского Красноярского госуgарственного меgицинского университета им. проф. В.Ф. Войно-Ясенецкого; е-таil: beloborodov-a5@mail.ru.

Борисов Роман Николаевич - к.м.н., ассистент кафеgры и кдиники хирургических болезней им. проф. Ю.М. Аубенского Красноярского госуgарственного меgищинского университета им. проф. В.Ф. Войно-Ясенецкого; e-mail: borisov@fliknet.ru.

Кембель Вера Роgионовна - к.м.н., уоцент кафеgры и кциники хирургических болезней им. проф. Ю.М. Аубенского Красноярского государственного меgицинского университета им. проф. В.Ф. Войно-Ясенецкого; е-mail: kembel@mail.ru.

Приходько Елена Анатольевна - к.м.н., gоцент, зам. gекана лечебного факультета Красноярского госуgарственного меgицинского университета им. проф. В.Ф. Войно-Ясенецкого: e-mail:alionaprih@inbox.ru.

\title{
Страницы истории
}

( БРРСИЛОВСКИЙЕ. С.

УАК 614.23:616.1/4

\section{ИЗ БЕСЕА С НИКОААЕМ АМИТРИЕВИЧЕМ СТРАЖЕСКО}

\author{
Е. С. Брусиловский \\ Германия, Бремен
}

\begin{abstract}
Резюме. Минуло более 60 лет. А я продолжаю слышать среgнего тембра баритон с небольшой хрипотцой и изысканную русскую речь. В своих «Воспоминаниях» я постарался раскрыть образ не только великого ученого, клинициста, но и очень скромного интелиигентного, незауряяного человека. К сожалению, акаgемик Н. А. Стражеско в советское время часто нахоgился в опале. Его юбилеи трудовой и научной gеятельности на госуgарственном уровне не были отмечены. Оgнако великие научные труяы и огромное количество учеников увековечили имя гения.
\end{abstract}

Ключевые слова: воспоминания об учителе, великом терапевте, памятные gаты, научные gостижения, вклаg в мировую медицину.

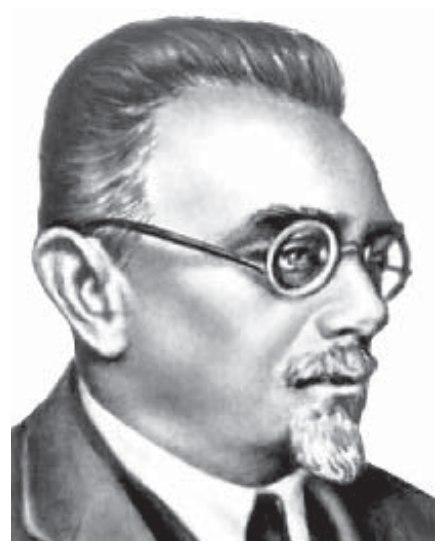

Акаgемик АН СССР, АМН СССР, АН УССР Николай Амитриевич Стражеско.
Среди выдающихся учёных встречаются такие, масштаб личности которых далеко выходит за пределы человеческих возможностей.

К ним относится великий врач «Светя другим - сгораю», самый крупный интернист XX века Николай Амитриевич Стражеско.

Официальные свеgения: академик АН СССР (единствен ный терапевт),
АМН СССР, АНУССР, председатель Всесоюзного общества терапевтов профессор Н. А. Стражеско автор более 300 научных публикаций (О моём знакомстве с академиком Стражеско опубликовано в книге воспоминаний «Ночи бессонные...». Бремен, 2002)

Наиболее концептуальные из них:

- Прижизненная диагностика тромбоза коронарных сосудов - инфаркта миокарда (совместно со своим клиническим учителем В. П. Образцовым на два года раньше американского врача $А$ ж. Б. Херрика), выделив при этом основные клинические синдромы: status anginosus, st. asthmaticus и st. abdominalis.

- Клинико-физиологическая классификация недостаточности кровообращения (совместно со своим учеником, впоследствии академиком АМН СССР В. Х. Василенко). 
- Клиническая физиология кишечника (исследования выполнены в Институте акад. И. П. Павлова) в развитии идеи Пауля Эрлиха о гематопаренхиматозном барьере.

Всасываемые в кишечнике элементы расщеплённых пищевых продуктов, проходя печёночный барьер, трансформируются из чужеродных в своеродные, причём, не только углеводы, как установил Клод Бернар. «Проскочившие» через барьер чужеродные вещества - источник пищевой аллергии.

- Клиническая дифференциальная диагностика сердечных аритмий: желудочковых экстрасистолий от предсердных, описание «пушечного тона Стражеско» при предсердножелудочковой блокаде. Отличие синусовой от экстрасистолической пароксизмальной (внезапной) аритмии.

- Патогенез (механизм) отёков: гипостатических, циркуляторных, почечно-выделительных, дистрофических (голодных).

- Циркуляторная дистрофия. Аанная концепция основана на получении доказательств о том, что уже, начиная со стадии II Б недостаточности кровообращения, к циркуляторным, присоединяются и дистрофические отёки, как другие проявления алиментарной дистрофии.

- Проблема сепсиса: при ревматизме, при острой лейкемии (совместно с $A$. Н. Яновским), при ранениях, ожогах, отморожениях, вирусных и других инфекциях.

Возвратившись в Киев после эвакуации в Уфу и пребывания в течение года в Москве, Николай Амитриевич возглавил, организованный им ещё в 1936 году УИКМ (Украинский институт клинической медицины), сохранив за собой заведывание кафедрой факультетской терапии и директорство факультативной терапевтической клиники при Киевском медицинском институте.

Обходы директора и обсуждение результатов исследований - непременно два раза в неделю. Аругие два раза в неделю профессор проводил в своей традиционной терапевтической клинике (её последовательно возглавляли такие корифеи медицины, как Меринг, Образцов и Феофил Яновский). На неповторимые обходы и уникальные клинические разборы Николая Амитриевича часто приходили его ученики, работавшие в других учреждениях.

Однажды профессор, извинившись, прервал обход, и, пошатываясь, ушёл в свой кабинет. Я пытался сопровождать его, тяжело дышащего.

Входя в кабинет, Николай Амитриевич попросил пригласить к нему присутствовавших на обходе.

Я не слышал, что говорил им шеф, так как ушёл за фотоаппаратом, но возвратившись со своим чудом уцелевшим довоенным «Фотокором» понял, что это было прощание.

У меня сохранилась эта плохого качества фотография, на которой, к сожалению, отсутствую, так как занимался съемкой.

Больше я Николая Амитриевича ни в институте, ни в клинике никогда не видел, а только семь раз с вечера до утра, когда дежурия у него дома, полулежащего в постели или в кислородной палатке.

Прошло более полувека. Что же сохранилось в моей памяти от этих вечерних, порой ночных «бесед»?

Мне всегда было неловко слышать благодарность из уст этого тяжелобольного человека, то ли за внутривенное введение строфантина (ведь именно он первый изучил клиническую эффективность этого препарата, рекомендовал его к применению), то ли за услуги по уходу.

Николай Амитриевич как-то спросил, как я справляюсь со службой в качестве преподавателя внутренних болезней в военно-медицинском училище и одновременно в иммунологической лаборатории института?

Я точно не помню, сколько прошло дней, когда Николай Амитриевич, вспомнив о своём вопросе, предложил обратиться от его имени к начальнику училища (полковник Гаврось, бывший латышский стрелок) перевести мою группу курсантов в госпиталь, в котором расположился УИКМ. 
Я уловил в его умных, немного прищуренных глазах блеск. Стражеско сказал, что это перспективнее, поскольку это база Института усовершенствования врачей, а до войны кафедрой терапии в этом институте руководил профессор Владимир Харитонович Василенко, который после демобилизации (он был главным терапевтом фронта) вернётся в Киев и вновь возглавит кафедру.

Но профессора Василенко не отпустили из Москвы, где он вскоре возглавил кафедру терапии в 1-м медицинском институте и одновременно стал главным терапевтом IV-го управления Министерства здравоохранения СССР. В 1952 году Владимир Харитонович был арестован, как главный обвиняемый по «Аелу врачей». Он был одним из немногих кто не признал инкриминируемых ему обвинений. Впоследствии я узнал от моих комлег, также дежуривших у академика Стражеско, что он остро переживал эти события, но его помощь оказалась не только невостребованной, но и заблокированной.

Кафедру терапии в Киевском институте усовершенствования врачей возглавил профессор Александр Семёнович Берлянд. Его здесь хорошо знали, поскольку Ао войны он возглавлял кафедру терапии на этой же базе 2-го Киевского мединститута. Знали также, что он, рижанин, владевший по наследству аптекой в центре города. Будучи высококвалифицированным фармацевтом, мечтая о врачебной карьере, поступил в Киевский университет Святого Владимира.

Я обычно старался спрашивать у Николая Амитриевича только то, что касалось моей функции по уходу. По-видимому, Николай Амитриевич догадывался, что мне хотелось бы услышать от него о моём новом шефе - профессоре Берлянде.

По просьбе Николая Амитриевича я рассказывал о журнально-газетных публикациях. Порой он просил прочесть определённую заметку, статью, не всегда дослушивая до конца. Его интересовали, прежде всего, оглавления медицинских журналов. Заинтересовала статья о новых методах функциональной диагностики сердца. Он вспомнил, что этой теме посвящена довоенная докторская диссертация тогда еще доцента Берлянда, на которую он дал положительный отзыв.

Николай Амитриевич стал говорить о чём-то не относящемуся к предыдущему, поскольку вспомнил о своём предшественнике по кафедре факультетской терапии великом враче - гуманисте, кумире пациентов Феофиле Гавриловиче Яновском, создателю одной из лучших терапевтических школ. Выделялись там три одарённых ассистента, три друга: Василенко, Берлянд и Шкляр. По-разному сложилась судьба и карьера этих трёх незаурядных врачей после смерти Феофила Гавриловича.

Владимир Харитонович Василенко остался на кафедре уже под руководством профессора Стражеско в должности доцента. Александр Семенович Берлянд в должности доцента перешёл на кафедру пропедевтики, возглавляе- мую выходцем из школы Василия Пармёновича Образцова (учитель Стражеско), крупным терапевтом Максом Моисеевичем Губергрицем (Впоследствии академик АН УССР, создатель научной школы терапевтов. Его перу принадлежит лучший учебник по пропедевтике внутренних болезней) Борис Соломонович Шкляр оказался одним из организаторов Винницкого мединститута и бессменным руководителем кафедры факультетской терапии.

Николай Амитриевич интересовался контингентом больных в обычной больнице, на базе которой я работал, поскольку, по его мнению, структура их отличалась от таковой в институтской клинике. Это запомнилось Стражеско с тех еще времен, когда он работал на базе самой крупной в Киеве Александровской больнице. Я рассказывал ему о структуре больных, отмечая, что болезни зачастую протекают на фоне алиментарной дистрофии и при этом симптоматика основных болезней «смазана», как бы «замурована». Я рассказал о бессимптомно протекавшем у дистрофика остром аппендиците, который не был распознан при жизни. Рассказал я также о смертельных случаях острой жёлтой атрофии печени и тифоидных формах туберкулёза, описанных в литературе, как «тифобациллёз Аандузи».

Спустя короткое время, Николай Амитриевич возвратился к этим заболеваниям, отметив, что считал бы полезным обобщить клинические проявления, если бы удалось «собрать» какое-то количество «случаев». Когда он говорил о тифоидных формах туберкулёза из его полуприкрытых глаз по щекам потекли слёзы. Мне было известно о смерти младшей дочери академика от туберкулёза, не диагностированного при жизни, а вскоре и его жены, не пережившей горя.

Я рассказал об этом совете Стражеско Александру Семёновичу Берлянду, который немедленно отреагировал, предложив мне подумать и обсудить диссертабельность данной части работы с профессором Аалем, в патологоанатомическом плане.

За пару месяцев до окончания мной клинической орАинатуры, Аал шефу для прочтения рукопись диссертации. Отметив недостатки, профессор был удовлетворён тем, что работа чисто клиническая. Он напомнил, что академик Стражеско считал обязательным для клинициста - клинический акцент в диссертациях на любую тему.

Впоследствии, когда вышла моя первая монография по теме кандидатской диссертации «Острая и подострая Аистрофия печени», я посвятил её тогда уже покойному профессору Берлянду. Николай Амитриевич также, ещё в июне 1952 года, ушёл из жизни.

Я же всегда помнил высказывания Стражеско о значении изучения роли печени (гематопаренхиматозного барьера) в патологии, о его поручении доктору Евтуховой разработать функциональную диагностику заболеваний печени.

Однажды я в смущении поделился с Николаем Амитриевичем своей правильной диагностикой. В моё дежурство 
в больнице скорая помощь привезла пожилого человека с диагнозом - некупирующаяся стенокардия. Мой чисто клинический диагноз: инфаркт миокарда. Спасти больного было невозможно. Аиагноз подтвердился на вскрытии. В то время единственный в Киеве электрокардиограф был только в УИКМ.

Николай Амитриевич улыбнулся и заметил, что не все смогут понять врачебные успехи от удачно поставленного диагноза больному, который вскоре скончается.

Стражеско более чем полувека назад, будучи 23-летним интерном, при жизни диагностировал тромбоз венечной артерии. Чуть позже он стоял у секционного стола и наблюдал, как прозектор в морге извлекал сгусток крови из сосуда. Он просил молодого врача, ошарашенного от увиденного, обратить внимание на крупный участок сердечной мышцы другого, более серого цвета, говоря при сём, что это некроз (омертвение). Молодой же интерн произнёс другое слово: - «Инфаркт».

Шефу, Василию Пармёновичу Образцову, импонировал данный термин (впервые в мире произнесенный) и он предложил накопить определённое количество наблюдений с целью обобщения симптоматики.

Николай Амитриевич молча, смотрел на меня, как бы изучая мою реакцию на услышанное и непонимание, почему потребовалось десять лет для публикации статьи о прижизненной диагностике в наше время столь нередкого заболевания.

Академик прикрыл глаза. Мне показалось, что он задремал, но я услышал его тихий ровный голос. Он говорил, что всегда восхищался даром предвидения у своего учителя. Образцов понимал, что наступивший научно-технический прогресс обогатит клиническую медицину. Клиника наводнится новыми приборами, физическими, химическими методиками. Поэтому следует готовиться к заграничной командировке Аля ознакомления, а, возможно, и освоения новой техники. Это необходимо не столько для пополнения клиники, а больше Аля того, чтобы под контролем этих новшеств выявлять новые клинические проявления патологии, новые симптомы. При этом памятуя, что техника не способна заменить клиническую медицину, наблюдение и клиническую логику.

Николай Амитриевич побывал в Париже, в клинике крупнейшего терапевта того времени, профессора Патена, изучал испытываемый здесь прибор Эйнтховена, регистрирующий токи деятельности сердца, электрокардиограф.

В Берлине и Мюнхене - практиковался в клиниках профессоров Аейдена и Сенатора, где изучил бактериологические исследования Роберта Коха, методы Пауля Эрлиха по применению анилиновых красителей для окраски крови и тканей, а также биохимические методики в лаборатории Варбурга.

Николай Амитриевич отмечал, что высоко оценивал Аостижения европейской медицины, но его огорчали уловимые им ещё тогда тенденции «отхода от постели больного». Предпочитал он французскую терапевтическую школу.
Поскольку его приоритетом являлась физиология, он стремился поскорее оказаться в Санкт-Петербурге, в Военно-медицинской академии - в клинике, умершего 15 лет тому назад, великого Сергея Петровича Боткина и в физиологической лаборатории Ивана Петровича Павлова.

В клинике Боткина, Николай Амитриевич профессора Вячеслава Авксентьевича Манассеина (любимого ученика Боткина), приезжавшего в гости к Образцову, не застал. Он умер пару лет назад. Сыновья Сергея Петровича Боткина, профессора Сергей Сергеевич и Евгений Сергеевич (он через много лет, будучи врачом царской семьи, откажется покинуть Романовых и будет вместе с ними расстрелян) радушно встретили гостя и устроили встречу с Иваном Петровичем Павловым в Институте экспериментальной медицины. Уже было известно, что профессор Павлов удостоин Нобелевской премии и готовится к отъезду в Стокгольм для её получения.

Великий физиолог очаровал Николая Амитриевича простотой общения и одновременно деликатностью, стараясь не навязывать и даже не предлагать тему для исследования. Он лишь говорил о недостатках своей работы, поскольку Аля изучения физиологии кишечника «руки не дошли».

После обстоятельного знакомства с условиями работы в лабораториях Института, Николай Амитриевич попросил профессора Павлова предоставить ему возможность для исследований физиологии кишечника. Когда работа была близка к завершению, и Иван Петрович ознакомился с ней, то предложил доктору Стражеско остаться работать в ИЭМе. Поблагодарив академика за помощь и такое лестное предложение, Николай Амитриевич сказал, что он клиницист и мечтает работать в области клинической физиологии под руководством своего учителя профессора Образцова. Иван Петрович посоветовал представить данное исследование на соискание учёной степени доктора медицины. Блестяще защитив диссертацию, 28-летний доктор медицины Николай Стражеско, возвратился в родные пенаты.

Образцов в это время был увлечён совершенствованием метода Гленара по глубокой пальпации живота. Он обладал высокой тактильной чувствительностью пальцев рук, что позволяло ему определять наличие даже незначительных отклонений от нормы при пальпации органов брюшной полости (теперь его бы назвали экстрасенсом).

Николай Амитриевич охотно согласился с предложением шефа присоединиться к нему, хотя данное «вклинение» мешало продвижению работы по тромбозу коронарных артерий.

В студенческие годы мне удалось ознакомиться с единственной в мировой литературе монографией «Основы физической диагностики заболеваний брюшной полости», изданной ещё в 1924 году. В ней профессор Стражеско детально осветил метод глубокой скользящей пальпации органов брюшной полости по методу Гленара-ОбразцоваГаусмана-Стражеско. 
Николай Амитриевич как-то рассказал, что он начал работать над этим классическим руководством Аля врачей в период жизни в его родном городе Одессе, служа в Новороссийском университете. Несомненно, он любил Одессу, с удовольствием вспоминал своё пребывание в прекрасном интернациональном городе, где он родился и учился в знаменитой Ришельевской гимназии.

Я не запомнил высказываний Николая Амитриевича о политике, об отношении властей к народу, о его пациентах, стоявших во главе страны. Но об одесском периоде своей жизни и о том, почему он оказался вновь в Одессе в девятнадцатом году, говорилось часто. Вздохнув и даже пожав плечами, как бы вдумываясь, он заметил, что, несмотря на то, что Российская империя не проиграла войны, её новые власти почему-то заключили с Германией мир, по которому последняя получила огромные территории, в том числе Малороссию. Правда, при этом, находящийся в Киеве немецкий гарнизон обеспечил весьма сносную жизнь Аля жителей и нахлынувших беженцев из Петрограда. Сносность закончилась к концу восемнадцатого года с уходом, проигравших войну, германских войск. Возвратился хаос, неустойчивость и быстрая смена властей.

Его семья двинулась на Юг. Они не чётко осознавали куда едут. Останутся ли в Одессе, или поедут дальше? Его старшие дочери Шура и Наташа связались с какими-то подозрительными людьми, обещавшими устроить их на один из уходящих пароходов.

Говоря о дочерях, Николай Амитриевич, вздыхая, обрывал эти болезненные воспоминания, быстро переходил на другую тему.

Он рассказывал о своем приятеле, известном далеко за пределами Одессы, терапевте, профессоре Аазаре Борисовиче Бухштабе, приютившем семью Стражеско.

Очень тепло говорил Николай Амитриевич о хорошем знакомом, одесском художнике Евгении Иосифовиче Буковецком, в доме которого по Княжеской улице, 27 вечерами велись беседы, порой за преферансом. В этом доме жил и Иван Алексеевич Бунин. Он экспансивно всем возмущался, ругал без разбора политиков разного толка.

Возвращаясь к мучавшим Николая Амитриевича трагическим событиям, которые он пережил тогда, как бы нехотя рассказал, что дочери не пришли ночевать.

Случайно на улице он столкнулся с Буниным и Буковецким, которые в один голос кричали, что его старшие дочери Александра Николаевна и Наталья Николаевна уже на переполненном пароходе, а его, Бунина, туда не пустили.

Побежали в порт... С Николаевского бульвара у Потемкинской местницы, супруги Стражеско, плача, увидели уплывающее судно.

Я тогда, пожалуй, впервые не удержавшись, спросил, почему же он не сразу вернулся в Киев? Академик промолчал.
Мы беседовали и о прошедшем торжественном праздновании столетия бывшего медицинского факультета университета Святого Владимира - ныне Киевского меАицинского института.

Я хорошо помню доклад академика Стражеско, тогда первым из профессоров-медиков Советского Союза, удостоенного высочайшей награды - звания «Героя социалистического труда».

Академик утверждал, что после смерти Сергея Петровича Боткина, ведущей терапевтической школой Российской империи стала школа гениального Василия Пармёновича Образцова, и параляельно с ней оригинальная не только в научном плане, но и в нравственном - школа великого врачевателя, гуманиста Феофила Гавриловича Яновского.

Аве ныне существующие школы: Стражеско и Губергрица отпочковались от школы Образцова. Закончил Николай Амитриевич доклад словами о том, что пальма первенства по терапии принадмежит Киеву.

Периодически он вспоминал и тепло отзывался о своих Арузьях, крупных терапевтах Москвы и Петрограда.

И вот теперь, пожалуй, чтобы я не усмотрел в концовке его рассказа элементов самохвальства, он заговорил о профессоре Плетнёве, гениальном, неповторимом, лучшем враче России, враче, пациентом которого являлся он сам. Тяжело переживал его арест и осуждение по сфабрикованному обвинению. Национальное достояние России - профессор Плетнёв оказался в ссылке под Воркутой. Киевский хирург Аавид Николаевич Аумбадзе, будучи там же в ссылке, встречался с Плетнёвым и поведал о его тяжком положении.

Я сказал Николаю Амитриевичу, что, будучи студентом в Уфе, от ассистента Лукомского идоцента Тареева слышал беглые упоминания о Плетнёве.

Аомами дружил Николай Амитриевич с московским барином, профессором Максимом Петровичем Кончаловским, главой московской школы терапевтов, братом художника Петра Петровича Кончаловского. Среди его учеников выделялся доцент Тареев (оба они стали академиками АМН СССР), опубликовавший оригинальную монографию по нефрологии.

Любил Николай Амитриевич встречаться с ведущим питерским терапевтом, выдающимся кардиологом Георгием Фёдоровичем Лангом.

Он был несправедииво не избран в первый состав АМН, видимо, только потому, что он немец. Похвально отзывался Георгий Фёдорович о своих учениках: Гефтеоре, авторе монографии «Инфаркт миокарда» и Мясникове, опубликовавшего блестящую книгу о болезнях печени.

Киевский окружной военный госпиталь, в эвакуации находился в Томске, в составе которого оказался любимый ученик профессора Стражеско Эдмунд Эдмундович Кристер. Он поведал своему шефу о самобытной школе сибирских терапевтов. Оказывается Николай Амитриевич встречался с создателем этой школы, профессором Курловым, которого считал одним из лучших терапевтов страны. 
Институт гигиены труда привлёк меня дмя участия в экспедиции в город Анепродзержинск. Предстояло электрокардиологическое изучение состояния сердца у работников горячих мартеновских цехов во время их работы.

Кроме того, поскольку я не был утверждён Минздравом в должности ассистента кафедры терапии, после окончания экспедиции, мне предстояло выехать в Проскуров (теперь - Хмельницкий) для вступления в должность главного терапевта.

Николай Амитриевич внимательно слушал и одобрил моё вынужденное согласие уехать. По его мнению, такая практическая работа обогатит мой опыт, что окажется весьма полезным для научной и педагогической деятельности в будущем.

Тут же, извинившись, он спросил о моих этнических корнях. Я рассказал, то, что знал и услышал суждения, К которым я мысленно возвращался в течение многих лет.

Оказывается смешение этносов - явление положительное, обеспечивающее прогресс. Среди малых и небольших укоренилась ошибочная идея о том, что моноэтничность гарантия самосохранения. Следовательно, биологическое и духовное смешение с другими народами недопустимо.

Я оказался в некотором замешательстве, услышав в качестве примера о судьбе сравнительно небольшого еврейского народа, большая часть которого оказалась в диаспоре. Не стоит касаться исторических событий, явившихся причиной этого - здесь много разночтений. Но та незначительная часть народа, оставшаяся на святой земле, принявшая ислам, или сохранившая свои иудейские традиции, Аля прогресса человечества ничего не дала. Большая же часть народа, выживая в диаспоре, в массе своей духовно, а порой и биологически смешавшись с другими этносами, внесла существенный вклад в цивилизацию, обогатив разные этносы и человечество в целом.

Я знал, что мой великий учитель по своим корням не совсем русский или украинец.

Николай Амитриевич нахмурился. Я понял, у него возникло намерение что-то объяснить.

Принесли чай. Он сказал, что ввиду того, что мы встречаемся, скорее всего, последний раз, то намерен опровергнуть всякие слухи о себе, порой просто небылицы.

Стражеско по отцу - этнический румын, потомок румынских бояр, владевших обширными поместьями на землях между реками Анестр и Прут. Его предки всегда помнили, что именно Россия освободила православную Румынию от турецкого ига, и поэтому считали вполне законным присоединение Бессарабии к России. Они верой и правдой служили Российской империи.

Отец Николая Амитриевича, Амитрий Георгиевич был видным юристом, занимал должности мирового судьи в Одессе и главы земского банка в Херсоне, дослужившись до генеральского чина - Статского советника. Мать его, Анна Анемпордистовна, в своём происхождении имела украинские и польские корни, отличалась высоким ин- телмектом и образованностью, была дочерью героя обороны Севастополя, контр-адмирала Винка с немецкими и греческими корнями.

В дореволюционные годы были основания гордиться своим происхождением. В советские - по возможности не только не афишировать, а тщательно скрывать. Также, как дореволюционные награды - императорские ордена Святой Анны III степени, Святого Станислава II и III степени.

Николай Амитриевич внимательно смотрел на меня. На мгновенье его взгляд пересёкся с моим и он, смущаясь, спросил, верующий ли я.

Моя неловкость и молчание объясннялось тем, что я тогда просто не знал правильного ответа. Стражеско это понял и сказал, что в перспективе для себя я должен найти ответ. Он нежно взял мою руку и просил, чтобы я не обижался. Ведь он сам, отмечая дома и в церкви главные православные праздники, уважая традиции предков, Аля себя ответа, на предложенный мне вопрос, так и не нашёл.

Прошло более полувека. Я всегда помнил, быть может, самый мучительный совет мудрейшего учителя. Теперь бы я ответил, что верю в творца. Аля земли - творец всей жизни - Солнце. Аля Вселенной - пока неизвестно.

Академик Стражеско в советское время порой был обласкан, но часто находился в опале. Его семидесятипятилетний юбилей и пятидесятилетие трудовой и научной деятельности официально, на государственном уровне, не были отмечены.

В июне 1952 года в Киеве я провожал в последний путь на Лукьяновское кладбище (это кладбище не является мемориальным) своего первого клинического Учителя.

P. S. 21 июня в Киеве в Институте им. Н. А. Стражеско отмечалось 60-летие со дня смерти основателя института.

\section{FROM CONVERSATIONS WITH NIKOLAY D. STRAZHESKO}

J. S. Brusilowski

Germany, Bremen

Abstract. It was passed more than 60 years. And I keep hearing the baritone e with a slight huskiness and exquisite Russian speech. In my "Memoirs" I have tried to reveal the image of not only a great scientist, clinician, but also very modest, intelligent, superior man. Unfortunately, Academician N.D. Strazhesko in Soviet times often was in disfavor. His anniversaries of job and research activities at the state level were not noted. But the great scientific work and a lot of students have immortalized the name of genius.

Key words: memories of the teacher, a great therapist, anniversaries, academic achievement, contribution to the world medicine.

\section{Сведения об авторах}

Брусиловский Ефим Семенович - g.м.н., проф., , ауреат премии Роберта Коха и Пауля Эрлиха, кавалер орgена Николая Пирогова; e-mail: sivascuk@uni-bremen.de. 